\title{
SISTEM INFORMASI PENJUALAN KEMASAN BERBASIS WEB PADA CV. GLADIES PACKAGING JAKARTA
}

\author{
Ependi $^{1}$ \\ ${ }^{1}$ Program Studi Manajemen \\ Universitas Mohammad Husni Thamrin \\ ependi71@yahoo.com
}

\author{
Ahlan Putra Rudiansyah ${ }^{2}$ \\ ${ }^{2}$ Program Studi Teknik Informatika \\ Universitas Mohammad Husni Thamrin \\ ahlanputrar@ymail.com
}

\begin{abstract}
Abstrak
Perkembangan ilmu pengetahuan dan teknlogi semakin pesat. Dunia usaha ikut terpengaruh perkembangan teknologi tersebut. Dunia usaha dapat memanfaatkan teknologi informasi yang dibantu dengan media komputer dalam melaksanakan kegiatan usahanya. CV Gladies Packaging yang merupakan salah satu perusahaan yang bergerak di bidang percetakan selalu inovatif dan kreatif dalam memecahkan masalah-masalah, dengan menerapkan sistem penjualan online yang bisa diakses dimanapun dan kapanpun. Penelitian ini membahas perancangan dan implementasi sistem penjualan berbasis web pada CV Gladies Packaging. Analisis dan perancangan sistem informasi menggunakan metode Diagram Flow Diagram (DFD).

Pada implementasi ditampilkan prototype penjualan Online, tools-tools yang digunakan, tampilan rancangan program, perangkat lunak, perangkat keras dan hak akses. Dapat disimpulkan bahwa kontribusi sistem penjualan Online dapat memaksimalkan berbagai bentuk penjualan, serta dapat dijadikan media informasi yang valid bagi seluruh aktivitas CV Gladies Packaging. Masyarakat secara umum dimanapun dan kapanpun dapat memanfaatkan sistem informasi berbasis web ini untuk melakukan transaksi pembelian pada CV Gladies Packaging. Bagi perusahaan sendiri, sistem informasi penjualan kemasan berbasis web ini mempermudah dalam penjualan barang, dan dapat meningkatkan omset penjualan.
\end{abstract}

Kata kunci : Sistem Informasi, Penjualan, Web

\begin{abstract}
The development of science and technology is increasing rapidly. The business world is also affected by these technological developments. The business world can take advantage of information technology assisted by computer media in carrying out its business activities. CV Gladies Packaging, which is one of the companies engaged in the printing sector, is always innovative and creative in solving problems, by implementing an online sales system that can be
\end{abstract}

accessed anywhere and anytime. This study discusses the design and implementation of a web-based sales system at CV Gladies Packaging. Analysis and design of information systems using the Flow Diagram (DFD) method.

In the implementation, online sales prototypes are displayed, the tools used, program design views, software, hardware and access rights. It can be concluded that the contribution of the Online sales system can maximize various forms of sales, and can be used as a valid information medium for all activities of CV Gladies Packaging. The public anywhere and anytime can take advantage of this web-based information system to make purchase transactions at CV Gladies Packaging. For companies themselves, this web-based packaging sales information system makes it easier to sell goods, and can increase sales turnover.

Keywords : Information Systems, Sales, Web

\section{PENDAHULUAN}

Perkembangan Teknologi Informasi yang disertai perkembangan Internet saling mendukung satu sama lain sehingga melahirkan konsep Teknologi Informasi berbasis Internet yang perkembangannya semakin luas dan semakin banyak diterapkan dalam bisnis perusahaan di berbagai bidang. Salah satunya CV. Gladies Packaging adalah sebuah toko yang bergerak dibidang penjualan dan pembuatan bermacam macam kemasan, contohnya seperti paperbag, kotak kue dan lain-lain. CV. Gladies Packaging ini memiliki pelanggan yang tersebar di dalam kota maupun di luar kota Jakarta dan telah menggunakan teknologi komputer untuk mendukung operasinya, tetapi system computerized masih terbatas dalam office automation untuk mendukung pemrosesan data, transaksi, operasi bisnis dan belum memanfaatkan Teknologi Internet. 
Berdasarkan hal tersebut diatas maka perlu dilakukan analisis, perancangan dan implementasi Sistem Informasi Penjualan berbasis web di CV Gladies Packaging, khususnya pada bagian pemesanan dan penjualan barang. Manfaat dari website ini bagi konsumen adalah mereka dapat memesan produk secara langsung dan dapat melihat produk yang akan dibeli melalui halaman website. Manfaat bagi perusahaan sendiri adalah dengan menggunakan website dapat meningkatkan penjualan dan keuntungan, disebabkan proses pemesanan dan pembelian lebih mudah.

\section{KAJIAN LITERATUR}

Menurut Tata Sutabri (2012:20) "sistem merupakan suatu bentuk integrasi antara suatu komponen dengan komponen lain karena sistem memiliki sasaran yang berbeda untuk setiap kasus yang terjadi dalam sistem tersebut".

Menurut Jogiyanto sistem adalah "suatu jaringan kerja dari prosedur-prosedur yang saling berhubungan, berkumpul bersama-sama untuk melakukan suatu kegiatan atau untuk tujuan tertentu".

Menurut McLeod sistem adalah "sekelompok elemen-elemen yang terintegrasi dengan tujuan yang sama untuk mencapai tujuan".

Berdasarkan beberapa pendapat yang diatas dapat peneliti tarik kesimpulan bahwa sistem adalah kumpulan bagian-bagian atau subsistemsubsistem yang disatukan dan dirancang untuk mencapai suatu tujuan.

Suatu sistem adalah jaringan kerja dari prosedur-prosedur yang saling berhubungan, berkumpul bersama-sama untuk melakukan suatu kegiatan atau menyelesaikan suatu sasaran tertentu. Suatu sistem yang baik mempunyai tujuan dan sasaran yang tepat karena hal ini akan sangat menentukan dalam mendefinisikan masukan yang dibutuhkan sistem dan juga keluaran yang dihasilkan.

Menurut Tata Sutabri (2012:32) informasi adalah "sebuah data yang diolah menjadi bentuk yang berguna dan berarti bagi yang menerimanya, informasi disebut juga data yang diproses atau data yang memiliki arti".

Menurut Sutarman (2012:13) sistem informasi adalah "Sistem yang dapat mengumpulkan, memproses, menyimpan, menganalisis, menyebarkan informasi untuk tujuan tertentu. Sebuah sistem informasi terdiri atas input (data, intruksi) dan output (laporan, kalkulasi)".

Menurut Tata Sutabri (2012:47) "Sistem informasi terdiri dari komponen-komponen yang disebut blok bangunan (Building Block), yang terdiri dari blok masukan, blok model, blok keluaran, blok teknologi, blok basis data, dan blok kendali. Sebagai suatu sistem, ke enam blok bangunan tersebut masing-masing saling berinteraksi satu dengan yang lain membentuk suatu kesatuan untuk mencapai sasaran".

Menurut Anita B. Wandanaya (Jurnal CCIT. Vol 5 No. 2 Januari 2012) Website dapat diartikan sebagai "Kumpulan halaman yang menampilkan informasi data teks, data gambar diam atau bergerak, data animasi, suara, video, dan gabungan dari semuanya baik yang bersifat statis maupun dinamis yang membentuk suatu rangkaian bangunan yang saling terkait dimana masing-masing dihubungkan dengan jaringan halaman (Hyperlink)".

Menurut Alexander F.K. Sibero (2011:11) Web adalah "Suatu sistem yang berkaitan dengan dokumen digunakan sebagai media untuk menampilkan teks, gambar, multimedia dan lainya pada jaringan internet".

Dari pendapat yang dikemukakan di atas dapat disimpulkan bahwa Web merupakan layanan yang dapat digunakan oleh pemakai komputer terhubung ke internet, baik berupa teks, gambar, suara maupun video yang interaktif dan mempunyai kelebihan untuk menghubungkan (link) satu dokumen dengan dokumen lainya (Hypertext) yang dapat diakses melalui sebuah browser.

Menurut Pressman, Roger S (2010:8) Aplikasi web yang disebut webapps, adalah "Kategori perangkat lunak jaringan sentris yang mencakup beragam aplikasi. Dalam bentuknya yang paling sederhana, webapps dapat menjadi link hypertext informatif yang menggunakan teks dan grafis yang terbatas". Namun, dengan munculnya Web 2.0, webapps berkembang menjadi lingkungan komputerisasi canggih yang tidak hanya menyediakan fitur stand alone (berdiri sendiri), fungsi komputasi, dan konten kepada pengguna akhir, tetapi juga terintegrasi dengan database perusahaan dan aplikasi bisnis. Berikut model aplikasi web: 


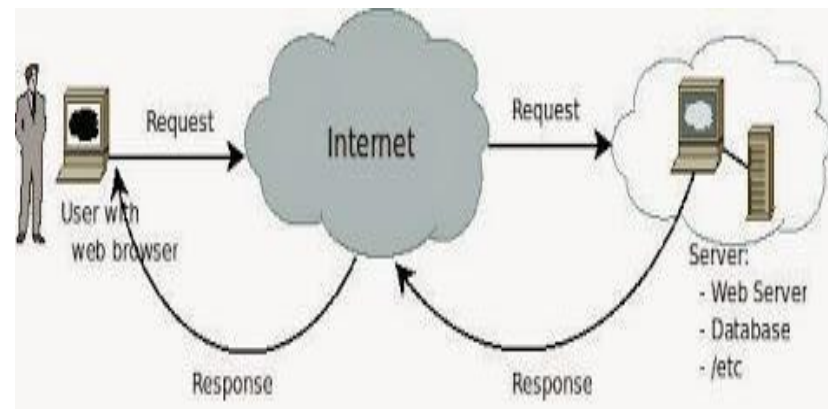

Siklus Request-Response aplikasi web

(c) bpdp.name 2010

Painted using dia - hittp://live.gnome.org/Dia

\section{Gambar 1. Model Aplikasi Web}

Menurut Tata Sutabri (2012:18) perdagangan electronik atau e-dagang (bahasa inggris : Electronic Commerce atau E-Commerce) adalah "Penyebaran, pembelian, penjualan, pemasaran barang dan jasa melalui sistem elekronik seperti internet atau telivisi, www (World Wide Web), atau jaringan komputer lainnya. E-commerce dapat melibatkan transfer dana elektronik, pertukaran data elektronik, sistem manajemen inventori otomatis, dan sistem pengumpulan data otomatis". Berikut adalah gambar ilustrasi ECommerce :

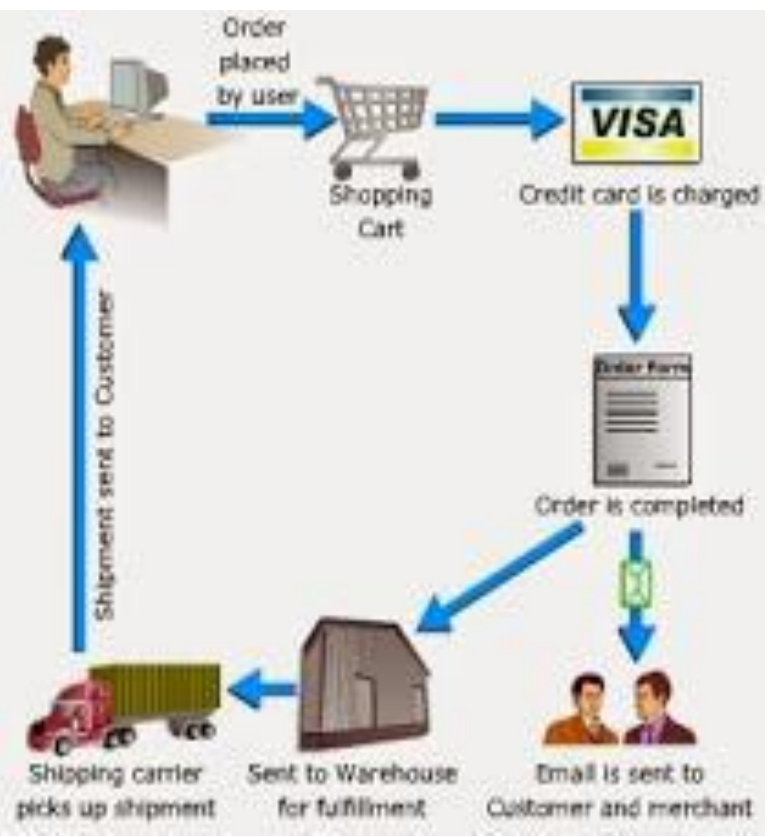

Gambar 2. Model Ilustrasi E-Commerce

Data Flow Diagram atau disingkat DFD merupakan suatu penggambaran model yang memungkinkan profesional sistem untuk menggambarkan sistem sebagai suatu susunan proses yang dihubungkan satu sama lain dengan alur data, baik secara manual maupun terkomputerisasi.

Menurut Fairuz El Sahid (2010) menyatakan bahwa "Diagram Alir Data (DAD) atau Data Flow Diagram (DFD) adalah suatu diagram yang menggunakan notasi-notasi untuk menggambarkan arus dari data sistem, yang penggunaanya sangat membantu untuk memahami sistem secara logika, terstruktur dan jelas". DFD merupakan alat bantu untuk menggambarkan atau menjelaskan. DFD ini sering disebut juga dengan Bubble Chart, Bubble Diagram, model proses, diagram alur kerja, atau model fungsi".

Menurut Indrajani (2011,p11) Data Flow Diagram (DFD) adalah "Sebuah alat yang menggambarkan aliran data sampai sebuah sistem selesai, dan kerja atau proses dilakukan dalam sistem tersebut". Dalam DFD ini terdapat empat komponen yaitu External Agents, Process, Data Store, Data Flow.

\section{METODE PENELITIAN}

Sistem baru yang diusulkan merupakan rancangan sistem informasi berbasis Web, pada sistem penjualan sebagai usulan atas sistem berjalan yang masih menggunakan cara manual. Adapun tujuan perancangan sistem berbasis Web adalah: Mempercepat proses pencarian produk sehingga customer dapat menerima informasi produk-produk yang dijual. Membantu dan mengatasi masalah yang timbul dalam proses penjualan produk kemasan. Mempermudah dalam penyimpanan data pemesanan barang dengan lebih teratur dan tepat waktu.

Pelanggan yang ingin membeli produk tidak harus lagi datang ke toko atau pabrik untuk bertemu dengan bagian pemasaran ataupun melakukan pemesanan barang melalui telepon ke bagian pemasaran. Pemesanan barang lebih mudah dengan bantuan aplikasi web.

Berikut rincian prosedur yang diusulkan: Pelanggan yang sudah melakukan regristrasi dapat mengakses data barang yang dijual kapan dan dimana saja. Pemesanan barang sudah tidak lagi harus datang ketoko maupun kepabrik, melainkan cukup dilakukan dimanapun dengan mengakses aplikasi web. Setelah Customer mendapat konfirmasi tentang pesanan, maka Customer melakukan transaksi pembayaran secara tunai yang ditunjukan dengan bukti pembayaran. Berdasarkan bukti setoran, kasir memproses transaksi pembayaran dengan membuka database 
penjualan (file barang, file customer, file faktur, file isi_faktur). Kemudian data pembayaran disimpan kedalam file bayar. Semua dokumen penjualan didistribusikan oleh kasir ke beberapa bagian seperti: Kwintasi Asli dan Faktur Penjualan asli diberikan ke Customer. Copy kwintasi dan Copy Faktur penjualan di berikan ke bagian akunting. Copy Faktur didistribusikan ke bagian penjualan, bagian gudang (Tembusan untuk pengeluaran barang).

Bagian akunting melakukan proses up-date transaksi penjualan berdasarkan file bayar dan file perkiraan yang disimpan ke dalam file jurnal. Prosedur yang diusulkan pada owner untuk mengecek laporan transaksi penjualan dan stok barang masuk.

\section{HASIL DAN PEMBAHASAN}

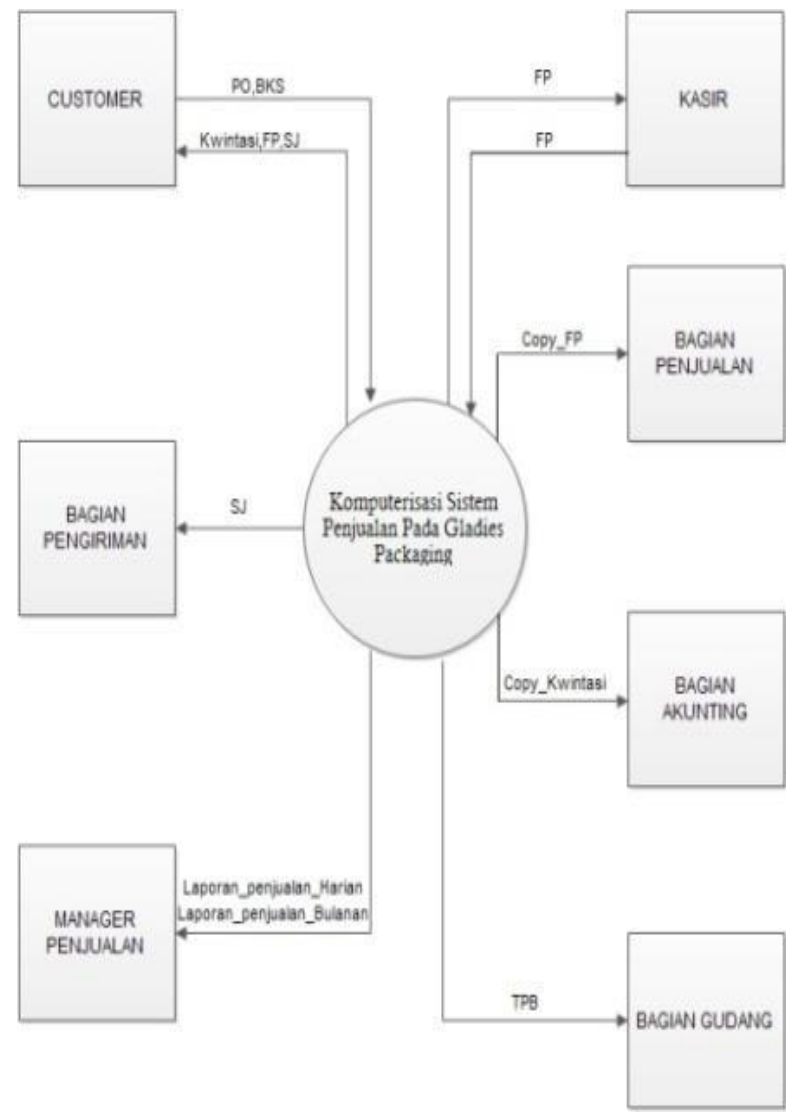

Gambar 3. Diagram Konteks Sistem Usulan

Pada Gambar 3 diatas, sistem Penjualan berinteraksi dengan entitas luar Customer, Kasir, Bagian Penjualan, bagian Pengiriman, Bagian Akunting, Manajer Penjualan, dan Bagian Gudang.

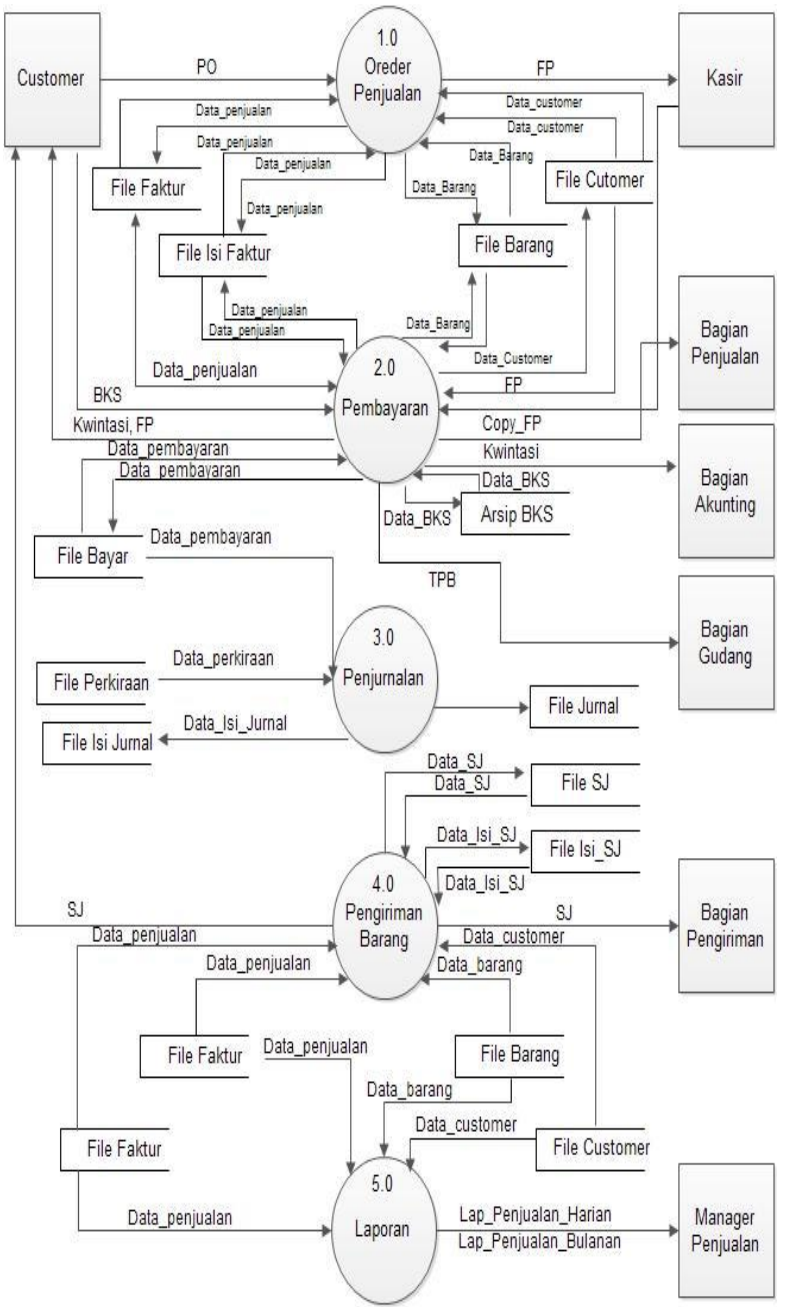

Gambar 4. Diagram Nol Sistem Usulan

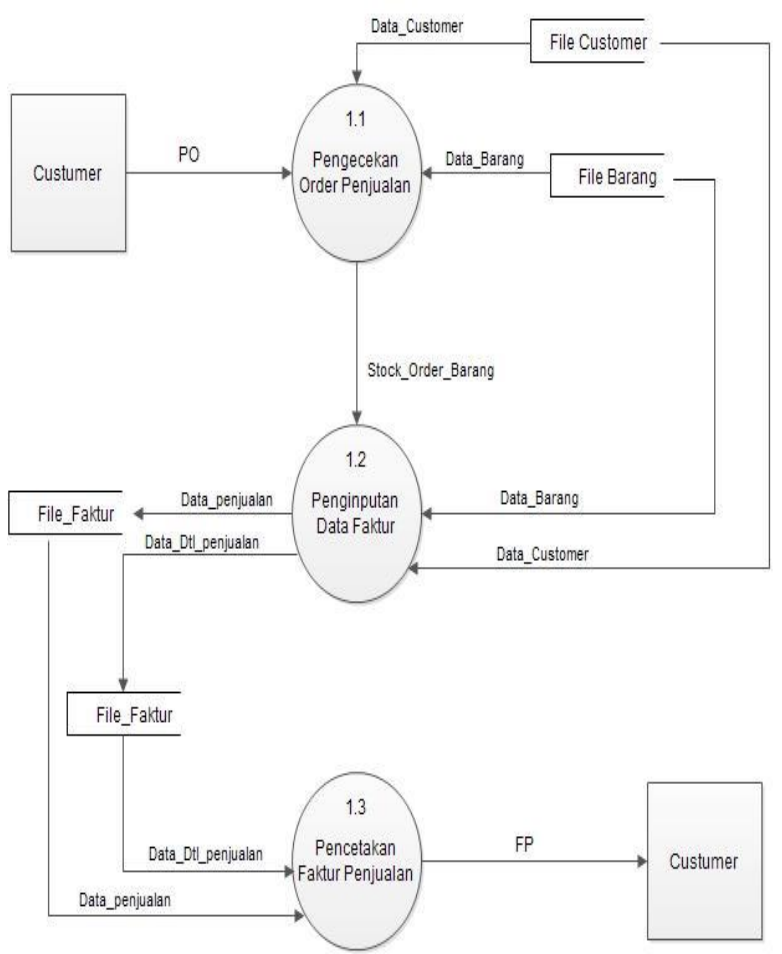

Gambar 5. Diagram Detail 1.0 Sistem Usulan 


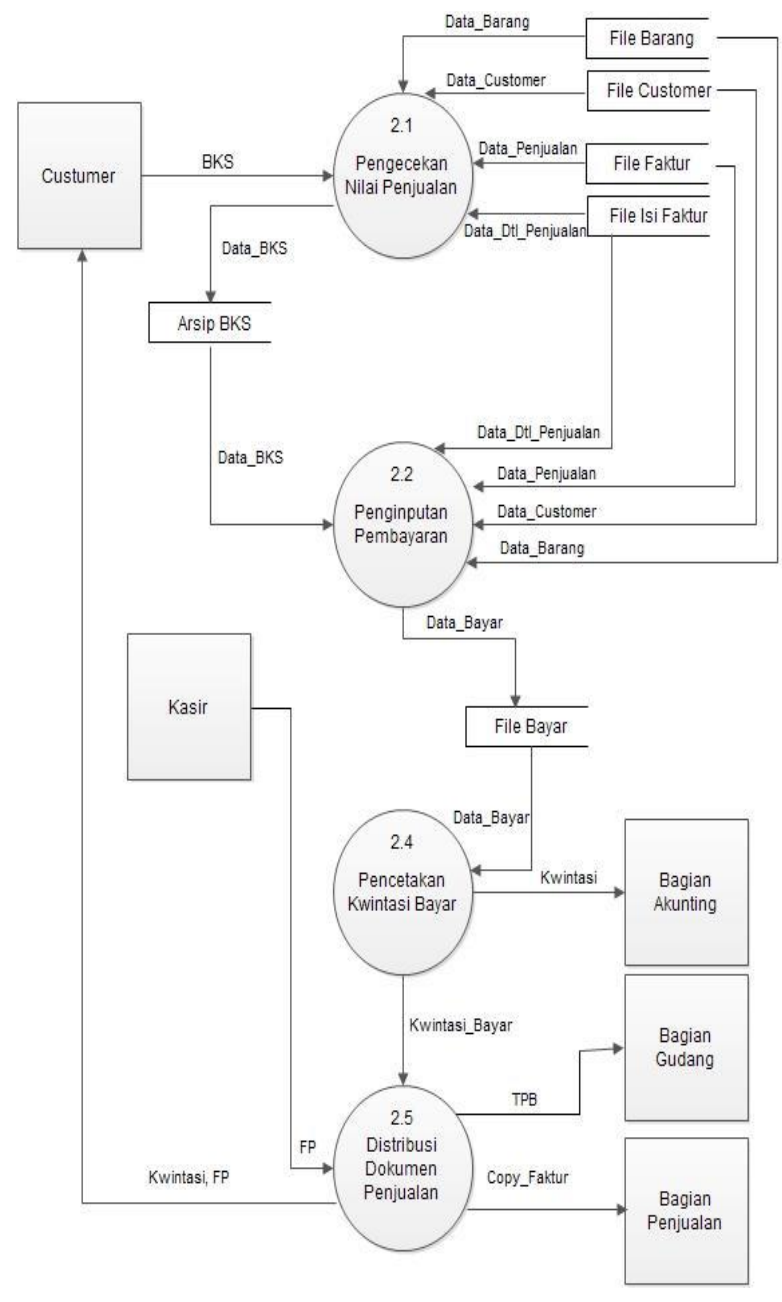

Gambar 6. Diagram Detail 2.0 Sistem Usulan

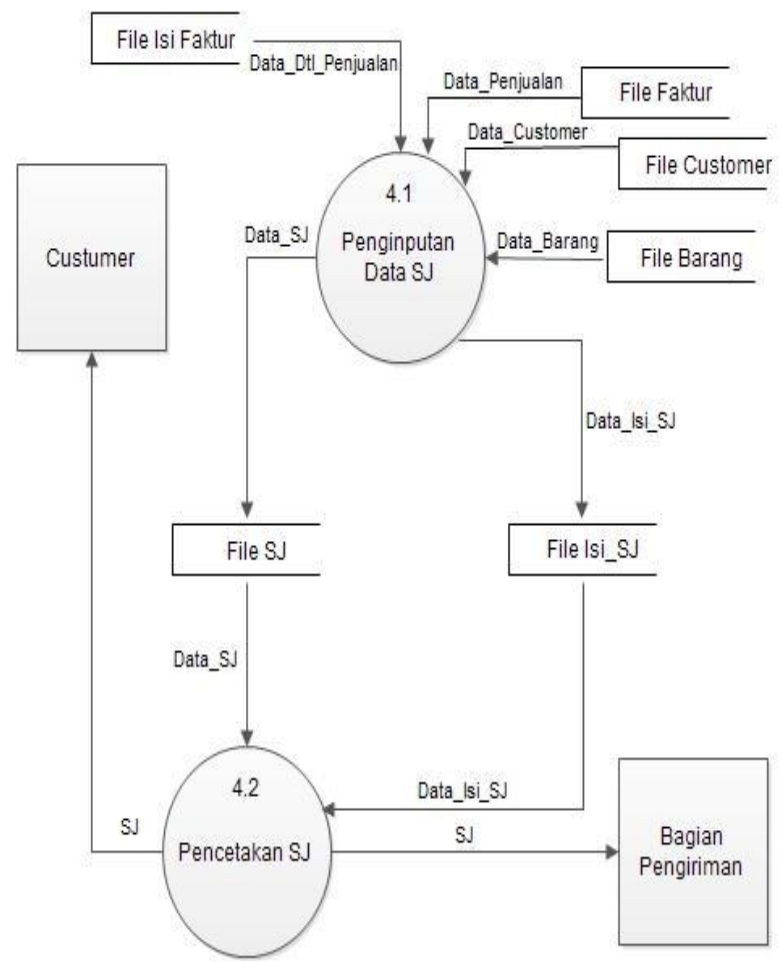

Gambar 7. Diagram Detail 4.0 Sistem Usulan

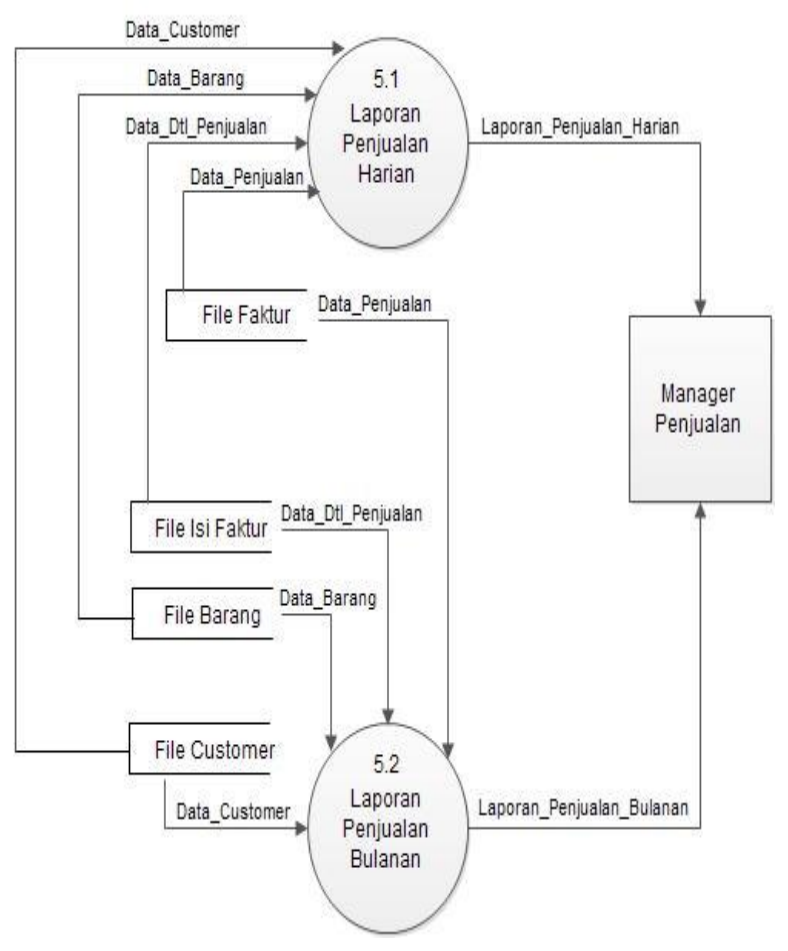

Gambar 8. Diagram Detail 5.0 Sistem Usulan

ERD merupakan diagram untuk mengorganisasi data pada databse dimana diagram ini menggambarkan hubungan entitas yang terdapat pada sistem.

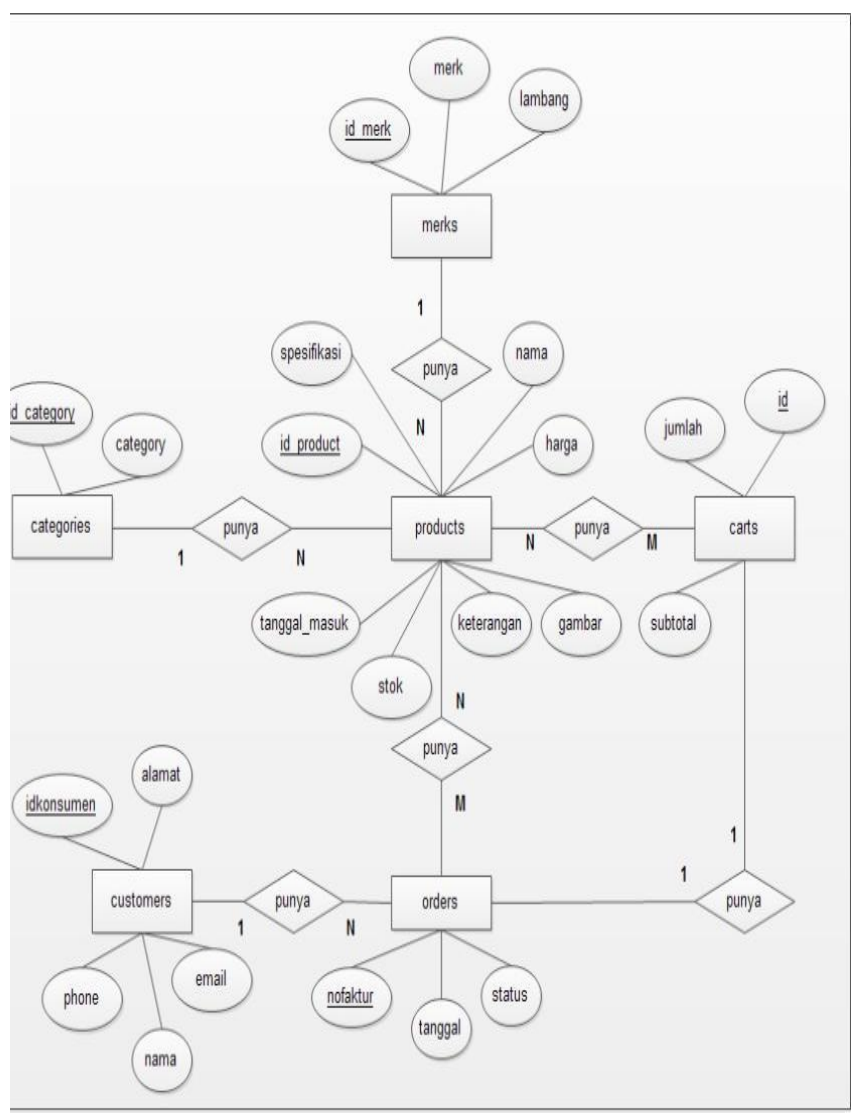

Gambar 9. Entity Relationship Diagram 
Dapat dilihat pada gambar 9, terbentuk beberapa relasi sebagai berikut : Satu categories mempunya $\mathrm{N}$ (banyak) products, dan banyak products mempunyai satu categories. Satu merk mempunyai $\mathrm{N}$ (banyak) products, dan banyak products mempunyai satu merk. Satu customer mempunyai $\mathrm{N}$ (banyak) order, dan banyak orders mempunyai satu customers. Satu carts hanya memiliki satu order, dan satu orders hanya memiliki satu carts. Satu products mempunyai M (banyak) orders, dan satu orders mempunyai $\mathrm{N}$ (banyak) products. Satu products mempunyai $\mathrm{M}$ (banyak) carts, dan satu carts mempunyai $\mathrm{N}$ (banyak) products.

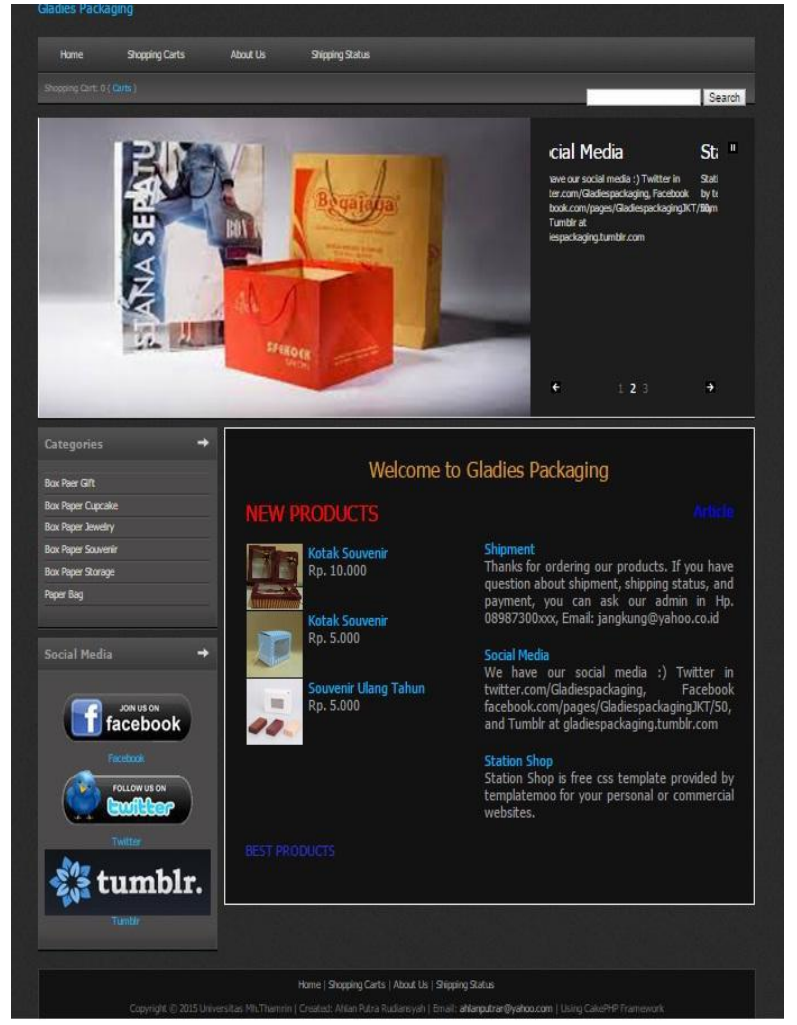

Gambar 10. Halaman awal

Gambar 10 ini merupakan halaman awal yang muncul ketika user berkunjung ke web site Gladies Packaging. Halaman ini menampilkan menu disebelah atas, daftar kategori disebelah kiri, dan footer paling bawah. Untuk konten sendiri berisi produk-produk baru, produk yang paling laris dipesan, dan artikel atau promosi.

Pada Gambar 11 berikut ini adalah tampilan dari katalog produk pada Gladies Packaging yang digunakan untuk mempermudah pelanggan dalam memilih produk yang ingin dipesan.

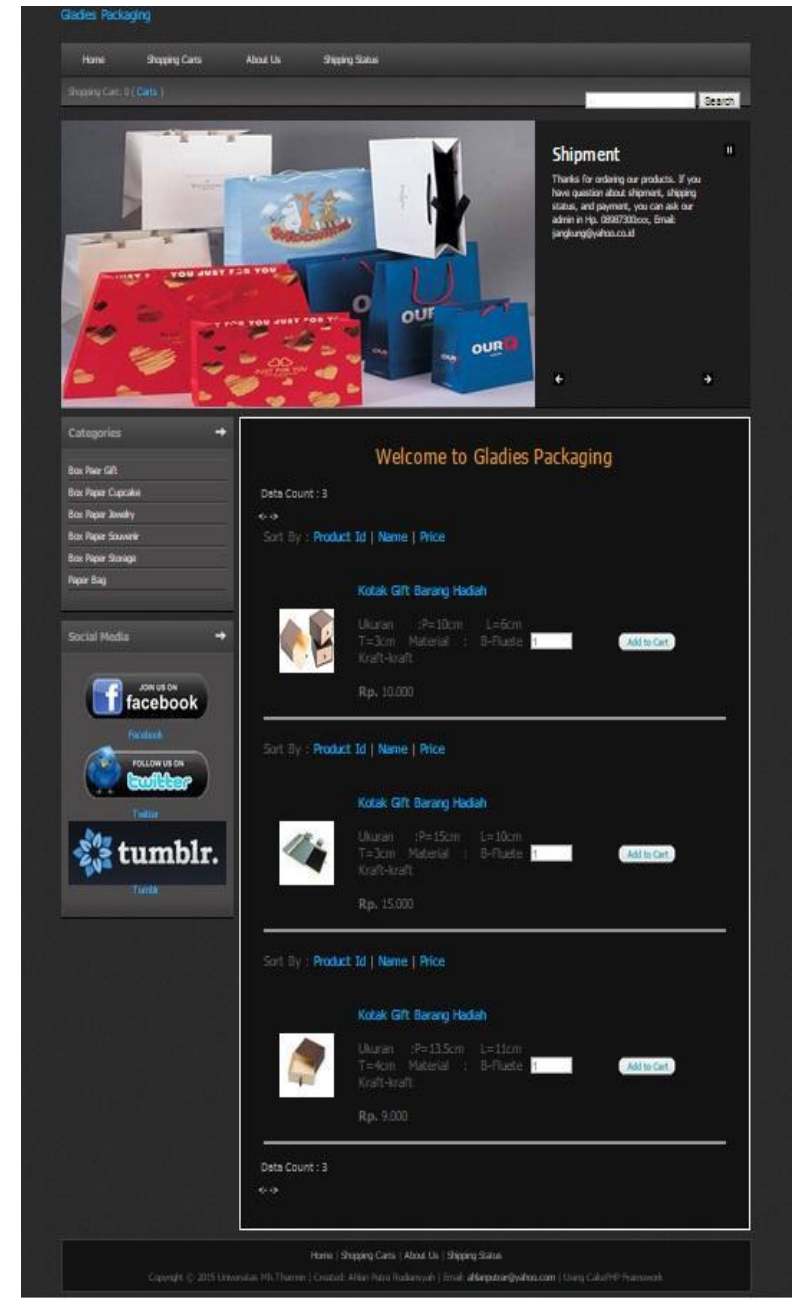

Gambar 11. Daftar Katalog Produk

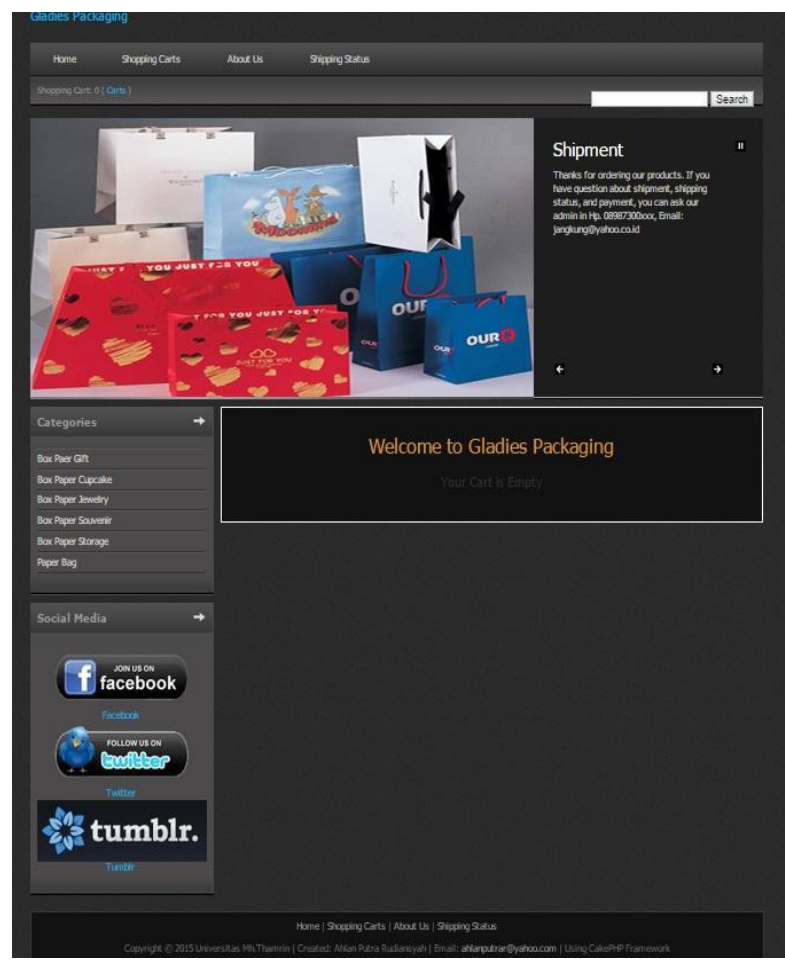

Gambar 12. Keranjang Belanja Kosong 
Pada Gambar 12 adalah tampilan dari keranjang belanja pada web Gladies Packaging untuk pelanggan melihat barang apa saja yang sudah di pilih dan ingin di beli.

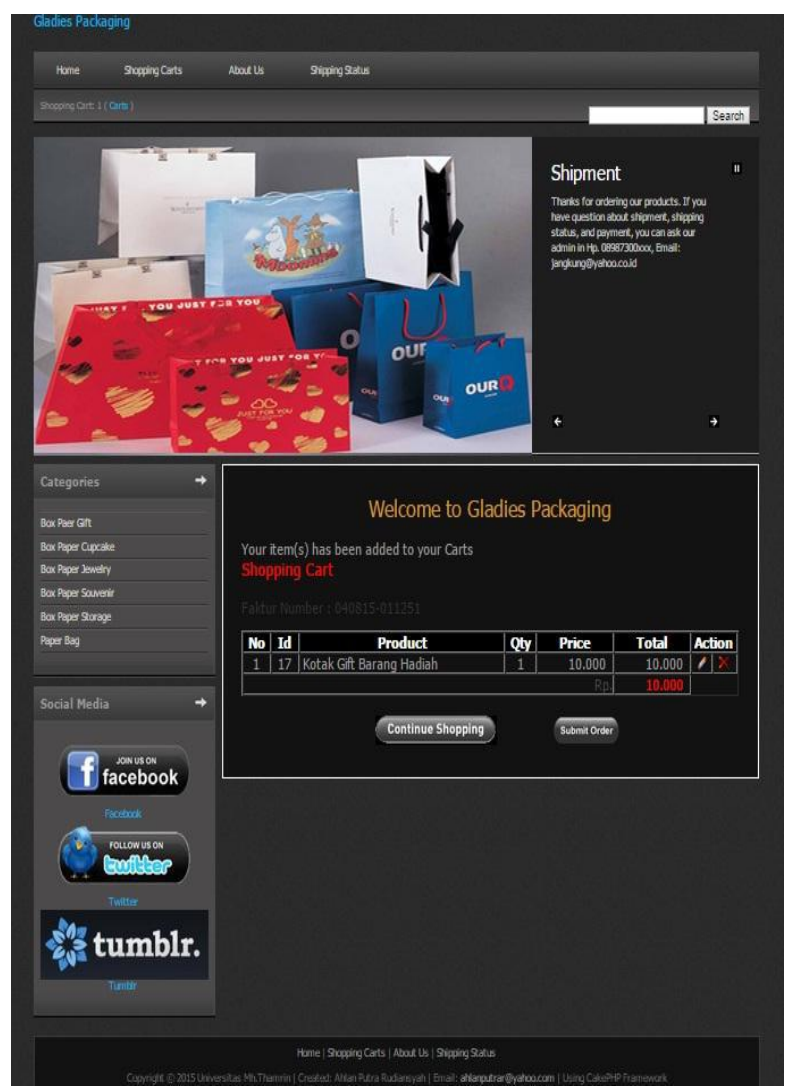

Gambar 13. Keranjang Belanja Terisi

Pada Gambar 13 adalah tampilan dari keranjang belanja pada saat pelanggan telah memilih barang yang ingin di beli.

Pada Gambar 14 berikut ini adalah tampilan dari riwayat pemesanan bagi setiap pelanggan yang sudah membeli produk pada web Gladies Packaging.

Pada Gambar 15 adalah tampilan dari pesanan yang sudah terkirim ke pelanggan.

Pada Gambar 16 adalah tampilan dari semua pesanan yang sudah dipesan oleh pelanggan.

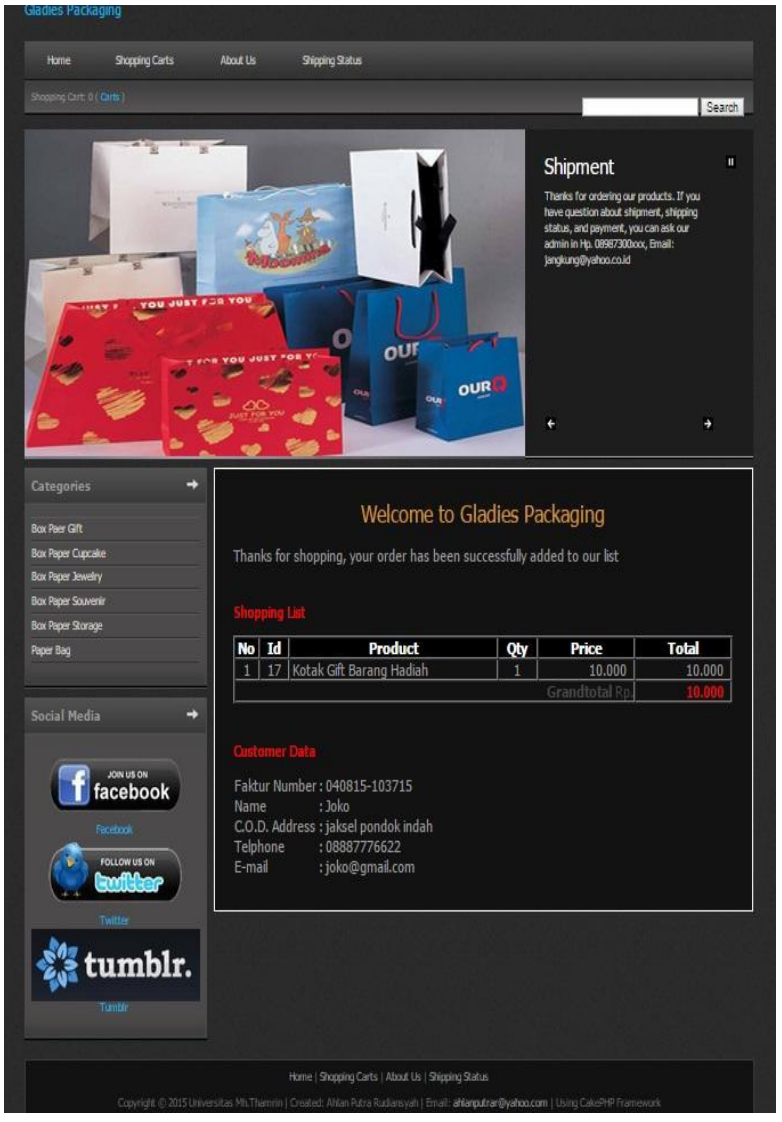

Gambar 14. Riwayat Pemesanan

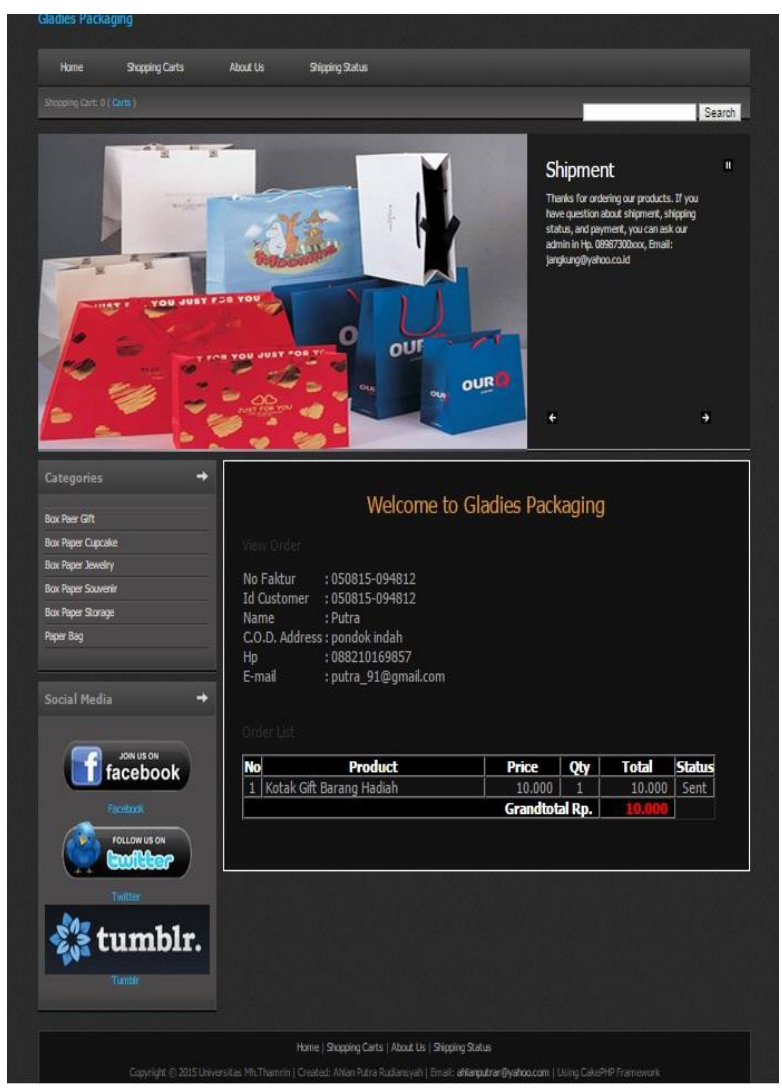

Gambar 15. Pemesanan Terkirim 


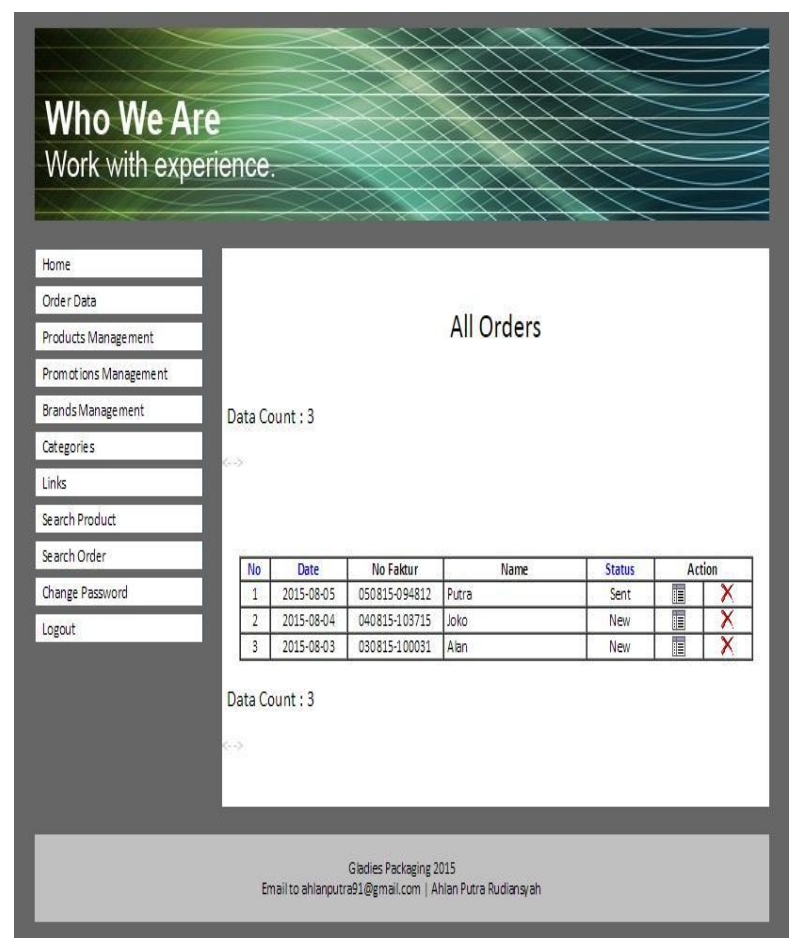

Gambar 16. Halaman data Pesanan

\section{KESIMPULAN DAN REKOMENDASI}

Kesimpulan dari penelitian yang telah dilakukan adalah sebagai berikut :

1. Sistem informasi Penjualan Kemasan bisa menjadi alat bantu dalam proses penjualan produk-produk dengan mudah.

2. Dengan adanya aplikasi Web ini, kinerja karyawan CV. Gladies Packaging dapat lebih maksimal di dalam pengolahan data customer.

3. Dengan adanya aplikasi Web ini, menjadikan proses penyimpanan data customer lebih terstruktur lebih baik dan efisien.

4. Dengan adanya aplikasi Web ini, mempermudah karyawan CV. Gladies Packaging dalam menambahkan suatu produk baru yang akan di pasarkan dan lebih mudah bagi customer untuk melihatnya tanpa datang langsung ke CV. Gladies Packaging.

Seperti yang terlihat dari hasil uji, aplikasi web ini masih jauh dari kata sempurna dan masih banyak kekurangan. Rekomendasi dari sistem mengenai produk yang cocok secara fashion, penambahan data spesifikasi dari sebuah produk, serta perbaikan tampilan bisa menjadikan aplikasi ini lebih baik lagi dan para pengguna bisa menjadi lebih nyaman dalam menggunakan aplikasi ini.

\section{DAFTAR PUSTAKA}

Alexanader F.K Sibero. (2011) Kitab Suci Web Programing, Yogyakarta: Mediakom.

Anita B. Wandanaya. (2012) Pengaruh Pemasaran Online Terhadap Keputusan Pembelian Produk. Jurnal CCIT, Vol 5 No. 2 Januari 2012.

Indrajani. (2011) Perancangan Basis Data. Elex Media Komputindo, Jakarta.

Jogiyanto. (2012) Pengantar Sistem Informasi, Jakarta: Graha Ilmu.

Kustiyahningsih,Yeni. (2011) Pemograman Basis

Data Berbasis Web Menggunakan PHP dan MYSQL, Jakarta: Graha Ilmu.

Mcleod. (2012). Pengantar Sistem Informasi, Jakarta: Graha Ilmu.

M. Rudyanto Arief, (2011) Pemrograman Web Dinamis Menggunakan PHP \& MySQL, Yogyakarta: ANDI

Pressman, Roger S. (2010) Software Engineering. A Practioner's Approach. 4th, MCGrawHill.

Sutarman. (2012) Pengantar Teknologi Informasi, Yogyakarta: Kanisius.

Sutabiri, Tata. (2012) Konsep Dasar Sistem Informasi, Yogyakarta: Andi Offset. 